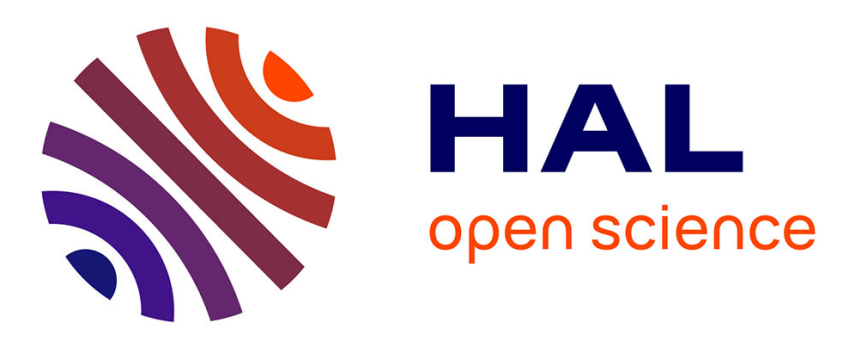

\title{
The Specificities of Relations between the State, Religious Communities and Civil Society in France
}

Edith Archambault

\section{To cite this version:}

Edith Archambault. The Specificities of Relations between the State, Religious Communities and Civil Society in France. Rupert Graf Strachwitz. Rupert Graf Strachwitz (ed) Religious Communities and Civil Society in Europe., Maecenata Schriften 16 Berlin, De Gruyter, volumeII, 2, pp.99-119, 2020, Analyses and perspectives on a complex interplay, 978-3-11-067299-2. halshs-02095725

\section{HAL Id: halshs-02095725 \\ https://shs.hal.science/halshs-02095725}

Submitted on 10 Apr 2019

HAL is a multi-disciplinary open access archive for the deposit and dissemination of scientific research documents, whether they are published or not. The documents may come from teaching and research institutions in France or abroad, or from public or private research centers.
L'archive ouverte pluridisciplinaire HAL, est destinée au dépôt et à la diffusion de documents scientifiques de niveau recherche, publiés ou non, émanant des établissements d'enseignement et de recherche français ou étrangers, des laboratoires publics ou privés. 


\title{
The Specificities of Relations between the State, Religious Communities and Civil Society in France
}

\author{
Pr Edith Archambault, \\ Centre d'économie de la Sorbonne \\ Paris1 Pantheon-Sorbonne University
}

This chapter presents the relations between religious communities and civil society with the State in France. Civil society is a third party of great importance in a country, which is widely considered internationally as highly centralised, having a specific culture placing the State above businesses and civil society. This French culture of "statism" may be viewed as follows: the State defines what a public good is and may conflict with the Church in this definition. The State has a kind of monopoly in providing public interest goods and services as a consequence. Therefore French citizens have an ambiguous relationship with the State: on the one hand, they dislike the high level of taxes and seek not to pay them if possible; on the other hand, French citizens considers that it is up to the government to deal with any civic, social, environmental or economic problem. ${ }^{1}$ Self-help is not a common reflex when a new problem arises. If government crowds out civil society, it will remain small according to the theory of social origins. ${ }^{2}$

This chapter discusses this a priori view of the specificity of France in Europe, where most Western countries belong to the "welfare partnership" characterised by high governmentfunded social spending, delivered partly by the central and local governments and partly through a large civil society sector. After centuries of prohibition or restriction, France's civil society sector is nowadays of the same order of magnitude as in most West European countries, which would seem to be in contradiction with the culture of "statism". The methodology used to discuss this contradiction is a multidisciplinary approach, more than an economic point of view, because in France as elsewhere, the historical background explains the present role, scope and weight of civil society. Historical, ideological and political conflicts with the State are at the root of the present position of the Catholic Church and other religions relative to civil society organisations.

The argument starts by giving a brief history of French civil society and its relationship with the State and the Church, highlighting the main similarities and differences with other

\footnotetext{
${ }^{1}$ Nearly two centuries ago, Tocqueville remarked this special relationship of the French to government: "In the end I understood that those hundred thousand Americans, frightened by the progress that drunkenness was making around them, wanted to provide their patronage to sobriety. They had acted precisely like a great lord who would dress himself very plainly in order to inspire the scorn of luxury in simple citizens. It is to be believed that if those hundred thousand men had lived in France, each of them would have addressed himself individually to the government, begging it to oversee the cabarets all over the realm". Tocqueville A.de (1835) Democracy in America, Edited and translated by Harvey C. Mansfield and Delba Winthrop Mansfield and Delba Winthrop, 2000.

${ }^{2}$ Salamon L, Sokolowski W and M. Haddock (2017): Explaining Civil Society Development, A social Origins Approach, Johns Hopkins University Press. ${ }^{2}$ Salamon L. and Anheier H. (1998) "Social origins of civil society"Voluntas, vol 9, 3.
} 
European countries. Then, the landscape of French civil society and religious communities nowadays is sketched out, while their relationships with the State are presented according to their components. Finally, the chapter focuses on the most conflictual part of French civil society, namely education, which has been the sources of a recurrent "school war" between the Church and the State. The conclusion notes that France is now a welfare partnership country as its Rhineland neighbours, even if relationships with religious communities are less developed.

\section{The Historical Background}

\subsection{The two common origins of European civil society in the Middle-Ages}

The origins of civil society organisations in France were similar in their roots to those in other European countries. They dated back to the Middle-Ages and were based on charities and guilds, notably the former, which were run by the Church through its parishes and congregations. They provided services in the field of education, essentially to reproduce the clergy; they helped the "good poor" - neither thieves nor vagrants - by providing food and shelter for them. Parishes organised "tables des pauvres" at the local level, similar to modern soup kitchens and France's current Restaurants du Coeur, while monastic orders welcomed the poor in asylums and hospitals. Hospitals specialised in health services during the late Middle-Ages. ${ }^{3}$ Medieval charities can be considered as ancestors of our modern systems of social protection, as well as service-providing civil society organisations.

In many European countries, some cities liberated themselves from the feudal order during the Middle-Ages. Guilds in these free cities and urban areas organised and certified the work of craftsmen and therefore they are considered as ancestors of labour unions and professional associations. The guilds had a social dimension: brotherhoods that gathered workers for recreation and the celebration of holidays at church. ${ }^{4}$ They also gave some assistance to their needy members, often the widows and orphans of deceased guild members. Therefore, brotherhoods organised a mutual assistance within professions, which later in the $19^{\text {th }}$ century developed into mutual societies.

In the most centralised and developed countries, France and England, the State replaced the feudal order earlier than elsewhere in providing external security and public order. In addition, an episodic concern for some social services occasionally appeared in France (the agency for the poor by King Louis IX - Saint Louis - or King François I), or in England (the Poor Laws).

\subsection{The big break point in civil society: the French Revolution and after}

The 1789 Revolution constituted the main difference in the historical path of France and other European countries. It abolished the two medieval pillars of civil society: on the one hand, the guilds and their social bodies, the brotherhoods, were suppressed in 1791 by the Le Chapelier Law, with the following rationale inspired by the philosopher Rousseau: ${ }^{5}$

\footnotetext{
${ }^{3}$ Mollat M.(1978), Les pauvres au Moyen-Age Hachette.

${ }^{4}$ In many medieval churches and cathedrals, chapels adjoining the nave have stained glass or statues celebrating the patron saint of a craft which were paid for by its guild and its brotherhood.

${ }^{5}$ Rousseau J-J. (1762 ) Le contrat social, google books, 1995.
} 
"No one shall be allowed to arouse in any citizen any kind of intermediate interest and to separate him from the public weal through the medium of supposed corporate interests."

On the other hand, the French Revolution fought the Catholic Church because it was in favour of Ancient Regime and the monarchy. Catholicism ceased to be the State religion in France. At the same time, repressive legislation against religious minorities - Protestants and Jews was suppressed. Congregations were expelled and the clergy had to acknowledge the Republic. Some priests did this, but others did not, especially in the western part of France, and were persecuted. A divide among the clergy arose as a result. In addition the revolutionary government needed money because of wars against European neighbours and the Catholic Church was rich. Therefore, its real estate was seized and sold to the raising social class, the bourgeoisie. Its hospitals and other charities were nationalised and run by public authorities. The Church also lost its tithes, a mandatory $10 \%$ tax on the income of the French, which was suppressed by the National Assembly in 1789. As the wealth of the Church has been partially devoted to the poorest part of the population under the monarchy, extreme poverty developed during this period of war between France and other European countries.

As a counterpart to the default of Church, the republican government stated that welfare was its own responsibility, according to the utopian position of the philosopher Montesquieu: "The state has to grant every citizen a livelihood, food, convenient clothes and a healthy way of life". ${ }^{6}$ In 1793, a Committee against Begging worked on social issues and set out these principles:

"Extreme poverty is the fault of the State...Public assistance to the poor is a sacred duty. Society owes poor citizens support and must either give them work or, if they are unable to work, secure them a livelihood."

These generous principles were not followed up by implementation because of the lack of public resources. The beginnings of implementation only appeared 150 years later. In the above quote from 1793, we can see a distinction between the poor who are able to work and those who are not; this distinction is also fundamental in the British Poor Laws.

In most European countries, both medieval pillars of the civil society became secularised and modernised step-by-step without such a revolutionary break and freedom of association was the rule in many countries in Europe. However, at the beginning $19^{\text {th }}$ century, Napoleon's repressive Penal Code outlawed any association of more than twenty persons, whatever its purpose, unless it had government accreditation and respected restrictive conditions. Subsequent governments either tolerated or repressed civil society organisations in a permanent conflict between an omnipotent centralised State and diversified social and political trends favouring the creation of associations, mutual societies and labour movements despite their prohibition or repression.

So France established freedom of association later than its neighbours. At the end of $19^{\text {th }}$ century finally, a series liberalising laws ended the limitations on freedom of association: labour unions were legalised in 1884, mutual societies in 1898 and all types of association were given legal recognition in the 1901 Law, which still exists. This Law defines an

\footnotetext{
${ }^{6}$ Montesquieu C. de (1748) De l'esprit des lois, Paris, Flammarion 1995.

${ }^{7}$ Quoted by Barthe M-A (1991) "Pauvreté et Etat-Providence. L'approche du Comité de mendicité" Revue Française des Affaires sociales, juillet-septembre. Ewald F. (1986) L'Etat Providence, Paris, Grasset.
} 
association as a "convention according to which two or more individuals permanently share a common knowledge or activity with a purpose other than sharing profits".

\subsection{Recurring conflicts between the State and Church that structure civil society}

France has always been a Catholic country: the beginning of France as a nation is considered to date back to the conversion of Clovis, the leader of the Franks, to the Roman Catholic faith at the end of the $5^{\text {th }}$ century. As the "eldest daughter of the Church", the Kingdom of France adopted Catholicism as its State religion.

However, there have been key differences in France's State-Church relationship, compared to its neighbours, and these are reflected in civil society. The relationship is more collaborative in countries where the State had signed a concordat with the Holy See and similar agreements with other Christian religions. In decentralised west-European countries, an early partnership in the provision of welfare services appeared at the local level. By contrast in France, and despite the concordat signed by Napoleon, there has been a recurring conflict between the State and the Church since the Revolution.

The causes of conflicts are many: after the restoration of the monarchy, the Church was partially compensated for the nationalisations of Revolution, which it judged as insufficient. With the compensation it received, the Church could not afford to rebuild its previous charitable network as it had existed before. It therefore concentrated implicitly on education which has been considered its most important activity by far, allowing for the transmission of faith. Later in the two last decades of $19^{\text {th }}$ century, a long-lasting "school war" began when the Republican State decided to create compulsory, free-of-charge, secular primary and secondary schools in order to reduce greatly the influence of the Church and to spread the Republican spirit. Finally at the end of this century, the Dreyfus affair divided France into two clans. Dreyfus was a Jewish army captain unjustly accused of being a spy. He was sentenced to banishment after a resoundingly anti-Semitic trial, although years later he was rehabilitated. Most Catholics and the army were anti-dreyfusards while most Republicans, Protestants and Jews were dreyfusards and denounced the collusion between the army, the Church and supporters of monarchy.

These conflicts in fact obscured the search for superiority on law and spirit of the French society. Similar conflicts also existed in other Latin countries where the situation of Roman Catholic Church was quasi-monopolistic. A first reconciliation occurred with the Law on the separation of Church and State in 1905, voted after a long and painful process. Article 1 of this Law stipulates that the State protects freedom of conscience and the exercise of worship. Article 2 asserts that the State neither recognises nor subsidises any form of worship. This Law also created specific organisations, called 'associations cultuelles' (associations of worship) to manage parishes. These worship associations have a broader legal capacity than the 1901 Law associations that could neither own real estate nor receive legacies. Congregations were also excluded from benefiting from the 1901 Law, because they do not accept free entry and exit. In 1905, a specific legislation concerning congregations was

\footnotetext{
${ }^{8}$ For more details on this crucial period, see Archambault E.(1996); The Nonprofit Sector in France, Manchester University Press, Johns Hopkins Sector Series 3 or Archambault E. (2001) "Historical roots of the nonprofit sector in France" Nonprofit and Voluntary Sector Quarterly, 130-2.
} 
decreed, and most congregations that had previously been expelled by strongly anti-clerical governments returned to France.

Despite the 1905 settlement, recurrent conflicts between the State and Church have structured the French civil society. As in many Latin countries, French civil society used to be shared between organisations of Catholic inspiration, some even obeying the directives of the Catholic hierarchy, and those of secular and republican inspiration. But this divide has faded now in France. ${ }^{9}$

\subsection{The historical background explains why French civil society is recent}

During the first part of $20^{\text {th }}$ century, successive governments were indifferent to civil society organisations which grew slowly. A philanthropic employers' movement appeared in the textile industry of the North and the East of France, providing social housing and health and social services to workers and their families. This movement was inspired by social Catholicism stemming from the Rerum novarum encyclical. The Catholic feminist movement was also close to this source of inspiration and was at the origin of social workers emerging as a profession: in the first years of the $20^{\text {th }}$ century. Some single middle-class women settled in deprived areas and created "social houses" to provide social and legal services to the poor. They also fought for women's liberation in society and Church and they were very active during World War I as nurses. The war was a turning point for civil society with the growing importance of the Red Cross and other emergency and relief organisations. ${ }^{10}$

After the war, the State provided assistance to war victims, including payments of war damages and veteran allowances. Some civil society organisations were created by persons with physical disabilities or their families, in order to demand similar support for the civil disabilities. These advocacy organisations remained small until the 1960s. A social security system began in the 1930s and was inspired by the German social security created by the Bismarck's government. It was enlarged after World War II into an extended welfare state, challenging mutual societies and civil society organisations. After 1960, the State began to support civil society organisations for the disabled, poor and elderly people or for child day care by allocating grants and third party-payments. As a result, civil society organisations mushroomed in the field of social services. For persons with physical or mental disabilities, small advocacy organisations created in the interwar period became large residential facilities to welcome and care for this population, because the State funded these residential care facilities up to $95 \%$ through third party payments. In this field, civil society organisations were - and still are - in a quasi-monopolistic position because they were the first to provide advocacy and social services.

The situation of civil society organisations is less monopolistic in social services for other people or the population at large, where the State actually supplies its own services. Social tourism (holiday camps and other facilities for workers and their families) was born when paid holidays were introduced in 1936, although the real boom came after World War II, like

\footnotetext{
${ }^{9}$ Baubérot J. (2015):Les Sept laîcités françaises, Paris MSH. Portier P. (2018): L'Etat et les religions en France: Une sociologie historique de la lä̈ité, Presses Universitaires de Rennes. For more details on the French legal position on Catholic Church and congregations see Castro S. "the law and the nonprofit sector" in Archambault E. (1996); The Nonprofit Sector in France, Manchester University Press, Johns Hopkins Sector Series 3. For a comparison of the legal position in European countries, see in this book Chapter... written by Tymen van der Ploeg.

${ }^{10}$ Guerrand R and M. Rupp, Brève histoire du service social en France Paris, Editions ouvrières, 1969
} 
the popular education movements and France's Houses of Culture. These associations aimed at democratising sports and culture

Ecology, feminism, defence of human rights, the Third World and anti-racism were all issues that characterised the wave of associations created before or after 1968. The 1980s and 1990s, marked by rising unemployment, were the period of fighting against social exclusion and integration by economic activity: WISEs ${ }^{11}$ multiplied to drive the long term unemployed to join the mainstream through work. "Without Borders" professional associations, devoted to international emergencies and development, including the famous "French Doctors", multiplied as well. After France's decentralisation Laws (1983 and 2003), which devolved power to the regions, all types of associations multiplied at the local level. Finally, demographic ageing also provoked an increase in home care services during the Millennium decade.

So in a nutshell, after centuries of suspicion, indifference or repression of civil society organisations, the French State changed its policy. Since the 1960s, a welfare partnership has appeared and it accelerated in the 1980s with the decentralisation that brought France's administrative system closer to its partners inside the European Union. Now central and local governments fund civil society organisations because they contribute to the welfare of the population. The last 40 years have therefore been characterised in France by a real "associative boom" that has marked the evolution of creations of registered associations. From an average of 5,000 associations created each year between 1901 and 1939, 10,000 in the post-war period, 20,000 creations in the 1970s, and 50,000 in the 1980s, an average of about 70,000 associations have been created per year since 2000. This associative explosion was prompted and has been accompanied by public authorities so that now French civil society has caught up its historical lag with its European neighbours.

\section{French Civil Society, Religious Communities and the State Today}

\subsection{The position of religious communities today in France}

Though France was historically the "eldest daughter" of the Catholic Church, regular religious practice is the lowest in Europe today, along with Denmark. Only 4\% of Catholics now go to Church nearly every Sunday, down from $27 \%$ in 1952. Official statistics on religious affiliation of the French are rare because, for reasons of principle, the French National Institute of Statistics and Economic Studies (INSEE) does not ask questions about race and religion in censuses and surveys. Private polling companies do so, but their samples are small and their results are often contradictory. Table 1 presents the results of the last official survey whose main topic was the fate of immigrant children, so that a waiver to normal data collection practices was obtained.

Table 1 Religious affiliation of the French

\begin{tabular}{|l|c|}
\hline No religion & $45 \%$ \\
\hline Catholic & $43 \%$ \\
\hline
\end{tabular}

\footnotetext{
${ }^{11}$ Social enterprises for work integration. Most of them are private and non-profit.
} 


\begin{tabular}{|l|c|}
\hline Muslim & $8 \%$ \\
\hline Protestant & $2 \%$ \\
\hline $\begin{array}{l}\text { Other } \\
\text { (Jewish,Orthodox, } \\
\text { Buddhist, etc.) }\end{array}$ & $2 \%$ \\
\hline
\end{tabular}

Source: INSEE/INED $2008^{12}$

Since the date of this survey in 2008, the percentage of the French people saying that they do not belong to any religion has likely increased, and people declaring that they are Catholic by tradition or culture has probably decreased.

Islam is now the second religion in France because of the waves of North-African immigrants after WWII and from sub-Saharan immigrants more recently; most Muslims surveyed in 2008 did not attend mosque regularly, but many young people have became more religious in the last decade under the influence of radical Islam and as a result of conflicts in the Middle-East. Protestants are few in France since the 1685 Révocation de l'Edit de Nantes; ${ }^{13}$ after this repressive law most French Protestants fled to Prussia or England. There are less than one million Jews, because of the Holocaust and emigration before WWII.

As a result, there is little religious diversity in France. Consequently, competition between religions in civil society organisations does not exist in France as in most European countries. The differentiation and emancipation in the secular sphere from the religious sphere began during the French Revolution and was reinforced with the 1905 Law separating Church and State. Religion is private and marginalised in the modern world, in accordance with the theory of secularisation by Habermas. ${ }^{14}$

\subsection{Relations between the State and religions nowadays}

Despite two Laws devolving power to the regions, central government in France keeps the bulk of power thanks to its presidential regime, while Parliament has less power than in many other European countries. Recently local and regional governments seem to have lost a part of their power and resources, as have political parties and labour unions as well as other intermediary entities. Jacobinism - the trend to centralisation - is indeed persistent as Rosanvallon has shown. ${ }^{15}$ The growth of civil society can be viewed as contradicting this trend to centralisation and France's culture of "statism".

Since the 1905 Law on the separation of Church and State, religion has been a private concern and the principle of laity/secularism is at the root of public education and administration. ${ }^{16}$ The French public sphere is secular, as in many modern European countries; moreover it is

\footnotetext{
${ }^{12}$ INSEE-INED (2008): Trajectories and Origins: Survey on the Diversity of the French Population INED Population Studies.

${ }^{13}$ A repressive Act by King Louis XIV that suppressed the toleration of protestant worship.

${ }^{14}$ Habermas J. (1964) The public sphere An Encyclopedia article. Habermas J. (2006) "Religion and the Public Sphere" European Journal of Philosophy 14.1.

${ }^{15}$ Rosanvallon P. (1981): La crise de l'Etat-providence, Paris, Le Seuil. Rosanvallon P. (2006) Le modèle politique français. La société civile contre le jacobinisme de 1789 à nos jours, Paris, Le Seuil.

${ }^{16}$ Portier P. (2018): L'Etat et les religions en France: Une sociologie historique de la laïcité, Presses

Universitaires de Rennes.
} 
laique. Laity is more than secularism. For example, it is forbidden to exhibit a sign of religious affiliation if you work in the public sphere, whether it is an Islamic scarf, a kippa or a cross. The same is true at school for pupils. ${ }^{17}$ These religious signs are tolerated in public spaces provided they are not ostentatious. Of course it is difficult to define how large an ostentatious religious sign is. The State is neutral: Catholicism is no longer a statutory religion but officials must not to show their faith in the public sphere. ${ }^{18}$ Prayers in official buildings, as in Anglo-Saxon countries, or the collection of taxes for religions, as in Germany or Italy, are unthinkable in France. And of course it is impossible to sing an anthem like "God save the Queen"19 or write on our banknotes "in God we trust". In fact there are several types of interpretation of laïcité according to regions and values. ${ }^{20}$ Generally religious people are more tolerant of the expression of religious signs in the public sphere than people with no religion.

Some exceptions to the Separation Law are currently being explored by the government to help organise the recent arrival of Islam in France. Self-organisation of Muslims and of Islamic worship has been recommended by the three previous governments, following the pattern of other monotheist religions. This has not been a success because of contradictory foreign influences that raised conflicts. Imams now mainly come from Saudi Arabia, Algeria or Morocco. Some of them do not speak French and most of them are far from the mainstream culture and values in France. The State also fears dissemination through mosques and social networks of Jihadism, an ideology that was at the origin of the recent terrorist attacks in France. A bill is now on the agenda to create new teaching tracks for imams and students intending to become imams in public universities, in order to socialise them in French culture through teaching humanities. This bill also proposes a tax on halal meat and on travel to Saudi Arabia for hadj. These taxes should be rerouted to the Islamic associations cultuelles to be created to fund the mosques and the Islamic worship, supplementing Muslims' private donations. Currently, most mosques are funded through 1901 law associations with less legal capacity than the 1905 Law on associations cultuelles. But these 1901 associations are not required to publish their accounts while 1905 associations cultuelles have to. Many mosques receive foreign money, especially from the Middle East, and the proposed changes are a way for the government to control them.

At the time of writing (January 2019), this bill had not yet been voted and maybe it will not be. It would constitute a great change of the law symbolising the relationship between the State and religious communities in France. ${ }^{21}$

\subsection{French civil society today}

\subsubsection{Number, size and human resources of French civil society}

\footnotetext{
${ }^{17}$ These religious signs are neither prohibited in private schools nor in universities

${ }^{18}$ Officials can enter in churches or other places of worship for funerals for instance, but they do not participate overtly in services. de Gaulle, probably the only practising Catholic president, instituted the habit of a presence without communion.

${ }^{19}$ Is it more correct to sing "Before an impure blood floods our fields" in our anthem?

${ }^{20}$ Baubérot J. (2015): Les Sept laîcités françaises, Paris MSH.

${ }^{21}$ Some exceptions to the 1905 Separation Law exist now, such as the fact that the annual contribution to parish costs may receive a tax deduction of $66 \%$ of the gift for the donating household, in the same way as giving to general interest associations and foundations. It is clearly a way for the State to "subsidise worship" indirectly. Another exception to Article 2 of the Separation Law is the fact that the State pays the members of religious communities to provide religious assistance and worship inside hospitals and prisons.
} 
The French non-profit sector is large and growing. In 2017, there were 1.5 million civil society organisations, operating mainly with two unequal legal statuses: about 1,500,000 associations and 2,300 foundations. Most associations are grassroots organisations run by volunteers active in the field of culture, sports and recreation mainly, but also operating in advocacy and social services. Only 157,000 associations are managed by a professional staff. About 2,000 associations have been granted the public utility label (Reconnaissance d'utlité publique) by the government, but many other associations operate in the public interest without having this label. Foundations are obviously a very small part of the French nonprofit sector, but it has been growing quickly since a favourable law in 2003.

French civil society is a major employer, providing $8 \%$ of total full-time equivalent employment (FTE). Of course associations are by far the main employer: they hire 1,852,000 employees (1,568,000 FTE) while foundations hire 86,000 employees (78,000 FTE). Employment in civil society is higher than in the construction or transport sectors. Most civil society organisations are small-sized: more than half of them hire only one or two employees and $70 \%$ hire less than five. However, $11 \%$ hire 20 employees or more and the largest organisations may have several establishments covering many regions. ${ }^{22}$

Social services are by far the main field of activity by civil society in France, as in most Western Europe countries (Table 2). Civil society organisations are also the main employer with $60 \%$ of total employment in this field in which the subsidiarity principle is applied: government does not provide a service if an organisation closer to beneficiaries can provide it, but government provides the bulk of its income. By contrast, the non-profit sector provides a small percentage of health and education services (10\% and 18\%), because the largest share of these services is public. In the culture, sports and recreation fields, $40 \%$ of total employment is in non-profit organisations

Tableau 2 Non-profit employment by activity, 31/12/2015

\begin{tabular}{|l|l|l|l|}
\hline Activity & Employees & $\begin{array}{l}\text { FTE } \\
\text { Employees }\end{array}$ & $\begin{array}{l}\text { \% of total } \\
\text { FTE } \\
\text { salaried } \\
\text { employment }\end{array}$ \\
\hline Health & 160,000 & 137,000 & $\mathbf{1 0 \%}$ \\
\hline Social services & 960,000 & 781,000 & $\mathbf{6 0 \%}$ \\
\hline Culture and recreation & 124,000 & 106,000 & $\mathbf{4 0 \%}$ \\
\hline Education, and research & 350,000 & 319,000 & $\mathbf{1 8 \%}$ \\
\hline Other & 344,000 & 303,000 & \\
\hline TOTAL & $\mathbf{1 , 9 3 8 , 0 0 0}$ & $\mathbf{1 , 6 4 6 , 0 0 0}$ & $\mathbf{8 . 0 \%}$ \\
\hline
\end{tabular}

Source INSEE-CLAP (2015)

Besides paid employment, volunteering is a main human resource for the civil society. The official statistical system ran two specific population surveys on volunteering for or through associations, in 2002 and 2010 and recently Lionel Prouteau conducted another one with the same questionnaire in 2017. These comparable surveys show a rapid increase of volunteering in the last decades, rising from 12 million persons in 2002 up to 22 million volunteers in 2017 (43\% of adult population). These 22 million volunteers worked 2.1 billion hours, equivalent

22 INSEE-CLAP(2015) Tableaux harmonisés de l'économie sociale. Tchernonog V.(2013): Le paysage associatif français, 2e édition, Paris, Juris-associations Dalloz. 
to $1,275,000$ jobs. This was one fifth less than paid employees, but in the same order of magnitude. Three quarters of volunteer work takes place in organisations where it is the only workforce, while one quarter is used by organisations hiring employees. In France, as in most European countries, the main destination of volunteering is the field of culture, sports and recreation ( $43 \%$ of volunteers' time). Then come social services (28\%), advocacy organisations $(16 \%)$, education and training $(5 \%){ }^{23}$

\subsection{Resources and the economic contribution of French non-profit sector}

The income of civil society organisations employing a staff come firstly from public funding, up to $56 \%$, while those without staff are less dependent on public money (26\% of their income). Public funding comes from central government, 101 départements, 35,000 municipalities and the social security system. However this public funding whatever its form - grants, contracts, competitive bids - is concentrated in education, health and social services, the industries connected with the welfare state. Fees and dues generate $40 \%$ of income in these fields and more than half of total resources for other industries than the three cited above. The income of grassroots civil society organisations without staff comes firstly from fees and dues but they also receive some subsidies from local authorities. Giving (household donations and corporate grants) is a minor but symbolic resource for both kinds of organisations, up to $5 \%$ of total resources on average, but some large charities rely mainly on donations. $^{24}$

The average budget of civil society organisations with staff exceeds $€ 400,000$. The total output of the French non-profit sector is about $€ 120$ billion, equivalent to $3.5 \%$ of GDP. The value added by the non-profit sector exceeds that of the hotels and restaurants $(2.6 \%)$ and utilities $(2.5 \%)$ industries and is of the same order of magnitude as the agriculture sector and food industry combined (3.4\%).

\subsubsection{The welfare mix}

Since the 1960s, civil society employment has grown twice as quickly as in the rest of economy. Today, the French civil society's record is high among European countries, after Netherlands, Belgium, the UK and Ireland, but ahead of Germany and other EU countries. Indeed it has caught up its historical gap. ${ }^{25}$ All these countries belong to the welfare partnership or corporatist pattern according to social origins theory.

Table 3 shows how welfare services are provided in France today.

\footnotetext{
${ }^{23}$ Prouteau L.(2018) Le bénévolat en France en 2017. Etat des lieux et tendances; Rapport de recherche, octobre 2018.

${ }^{24}$ Tchernonog, V. (2013), Le paysage associatif français. Mesures et évolution, Paris, Juris-éditions et Dalloz. Tchernonog, V. (2018), Les associations : Etat des lieux et évolutions, ADDES.

${ }^{25}$ Salamon L. and alii (2017): Explaining Civil Society Development, a Social Origins Approach Johns Hopkins University Press.
} 
Table 3: The breakdown of paid employment in public services across the private, nonprofit and public sectors, in 2011

\begin{tabular}{|l|l|l|l|l|}
\hline Area & Non-profit & Public & For-profit & Total \\
\hline Education & $\mathbf{1 9 \%}$ & $76 \%$ & $5 \%$ & $100 \%$ \\
\hline Health & $\mathbf{1 2 \%}$ & $65 \%$ & $23 \%$ & $100 \%$ \\
\hline Social services & $\mathbf{6 2 \%}$ & $28 \%$ & $10 \%$ & $100 \%$ \\
\hline $\begin{array}{l}\text { Share of total } \\
\text { employment }\end{array}$ & $\mathbf{7 . 5 \%}$ & $\mathbf{2 5 . 5 \%}$ & $\mathbf{6 7 \%}$ & $\mathbf{1 0 0 \%}$ \\
\hline
\end{tabular}

Source: Archambault E.(2017):"The Evolution of Public Service Provision by the Third Sector in France" The Political Quarterly, vol 88, N³.

Table 3 shows the variety of the welfare mix according to the main areas of welfare policy. In terms of education, the public sector accounts for the lion's share of jobs. Most higher education is therefore public, and practically free. The presence of private companies is recent and growing. At the end of the Millennium decade, it was limited to private tutoring and "cramming" services for students preparing competitive exams to enter certain establishments, but it is now expanding in higher education. The civil society sector hires $19 \%$ of education employment. It provides schooling for one fifth of all pupils in primary and secondary schools, $90 \%$ of which are Catholic schools. These establishments operate under contract with the State and will be examined below. In higher education, aside five small Catholic universities, non-profit sector runs most business schools, as well as most of the training for nurses and social workers. In addition, lifelong vocational learning is provided by non-profit organisations and private companies, and is financed through a special type of business tax.

The provision of health services is spread much more evenly between private companies, civil society organisations and public institutions. Public and non-profit hospitals are free of charge and paid directly by the French social security health insurance system. Private clinics are mainly funded by social security as a third party, but patients have to pay a more or less important share of care services, according the clinic's comforts, the renown of the doctors, and so on. Conversely, doctors and other professionals delivering health services outside the hospitals are paid, at least initially, by their patients; they are mainly private, self-employed professionals or they work in small standard enterprises. Yet they are highly regulated by the State and the social security system, which mainly reimburses their patients. Non-profit hospitals and other human health activities represent $11 \%$ of the total delivery of health services. They are particularly active in the fields of cancer treatment, rehabilitation for every kind of disability, as well as drug and alcohol-addiction treatment. All these specialties are labor-intensive.

Associations and foundations are the main employers in social services: they hire $62 \%$ of employees working in these activities. They even have a virtual monopoly for residential establishments and assistance at work for people with disabilities. The penetration of private companies in this field is recent and mainly concerns retirement homes and other establishments for the elderly: major hotel chains have recently started diversifying into this sector which is forecast to grow strongly. The public sector is also very present for establishments and services for the elderly, though its share is declining. Moreover, the public 
sector runs the majority of services looking after children under three years old in crèches. But, associative and company crèches also exist. For children aged 3 to 6, public kindergartens cater to nearly all children and become compulsory recently. Finally, social services for home help are largely provided by associations. However, since a 2005 Law which provides the elderly and disabled with vouchers (the job-service cheque, i.e. chèque emploi service) this near monopoly is being eroded, as private companies have entered the market significantly, cream skimming clients with high incomes.

To summarise, a powerful mixed economy has emerged in these three welfare fields, and particularly so for social services, where a strong pattern of government-civil society cooperation has emerged since the 1960s, while a kind of division of labour has been gradually established between public and private non-profit hospitals. Such partnership was more difficult to establish in education, the realm of Catholic Church after the French Revolution.

\section{Recurrent Conflicts between the State and the Church in the Field of Education}

This section focuses on the part of civil society where the competition between the Church and the State was the tougher and longer, leading to open conflict on many occasions. This long-lasting conflict between the secular State and the Catholic Church during the two last centuries has been multidimensional and has concerned faith, values, influence, power, ethics, political and civic teaching, etc. Entering school is indeed for a child his/her first step into the public sphere and governing this first step was and still is a vital issue for both competitors.

\section{1. "School War" between the State and the Catholic Church in $19^{\text {th }}$ century}

During the Revolution and the ensuing French Empire, public universities were created and Napoleon gave them the monopoly to grant national degrees, which still exists today. At the same time, an Ecole Normale Supérieure was also created to train teachers and professors of secondary and tertiary education. When the Monarchy was restored in 1815, the Church used its compensation for property lost during the Revolution to rebuild its school network as a priority. Some congregations came back to France and devoted their activity to education, the most famous being the Jesuits. Until the second part of the 19th century, primary and secondary schools were a quasi-monopoly of the Church and its religious orders. Working class people and peasants never went to school or only for short periods. The 1830 Guizot Law encouraged municipalities with over 500 inhabitants to create primary schools, for boys only, but this Law was only partially implemented because of a lack of public financing. Later, the 1850 Falloux Law authorised anybody to create a primary school and any qualified person to open a secondary school. ${ }^{26}$ Private Catholic schools multiplied after this Law, especially in the Western, most religious part of France. These private schools were de facto intended for middle-class children whose parents could pay the rather high fees.

During the three last decades of $19^{\text {th }}$ century, the Republican government desired to reduce the Church's influence because it favoured monarchy. In 1882, Jules Ferry introduced compulsory schooling, free of charge and a secular network of public schools. He created specialised schools to train teachers to the required level of qualification, but also in Republican and anticlerical values. Public teachers were Republicans and, as rationalists,

\footnotetext{
${ }^{26}$ Public subsidies to those "free"schools had to stay below one tenth of total expenses
} 
they fought superstition, often assimilated with the influence of clerics. And so the school war went on.

\section{2. "School War" between State and Church and Reconciliation in 20th Century}

From 1882 till the 1950s, the public school network was the only one to be financed by government with the exception of small subsidies granted to the private schools that had to cover less than $10 \%$ of their expenses according to the Falloux Law. Accordingly, parents who chose private schooling for their children denounced this situation; they argued that they paid twice for education, through their taxes for the public schools and through the fees paid to the private schools of their children. They lobbied successfully for a change in the financing of private schools despite the opposition of the left-wing parties. In 1951, the Barangé Law abolished the prohibition of subsidising private schools above $10 \%$ of their budgets. In 1959, the Debré Law established the so-called the contrat d'association which is still in operation and which most private non-profit schools have adopted. According to this contract, private schools have to follow the same programs as public schools. ${ }^{27}$ In exchange, France's central government pays teachers who work in private schools but who have the same qualifications as those in public education, while municipalities pay for other costs including accommodation for primary schools, and France's regions pay for high schools. Parents therefore generally pay rather low fees (€850 on average per year).

The 1950s were indeed the beginning of a kind of partnership in the conflicting field of education. After this change, the "school war" calmed down despite some subsequent resurgences, the most important being the 1984 conflict. The then socialist government under François Mitterrand, with the agreement of the French Bishops' Conference, tabled a bill which unified public and public-subsidised private education in a "great public service of education". This bill was inspired by the Belgian and Dutch systems of education and by the situation prevailing in France for public and non-profit hospitals ${ }^{28}$. However Catholic schools saw this bill as a loss of pedagogical and ideological independence. Large demonstrations with up to one million people in Paris took place and the government felt obliged to scrap its proposed reform. This revival of "school war" and some other less important events show that consensus about education in France has still not been completely reached.

\subsection{The present position of private non-profit education}

While the "school war" has indeed calmed down, $90 \%$ of private education is loosely Catholic inspired. According to their contract with the State, Catholic schools have to welcome pupils of any or even no religion. Attending Mass cannot be compulsory. There is also no discrimination for teachers who are public officials recruited by competition, like those in public education and paid directly by the State. Teachers cannot be dismissed because of their marital status or sexual orientation. Protestant children usually attend public schools for historical reasons and this used also to be the same for the Jewish children. But now Jewish schools are multiplying since the rise of anti-Semitism in some public schools. A few Muslim

\footnotetext{
${ }^{27}$ Detailed programs are mandatory in primary and secondary schools (not in tertiary education). Religious education can be added inside private schools.

${ }^{28}$ In the 1920s, a political compromise put an end to the long-standing conflict between the Dutch state and Catholic and Protestant churches in the field of education This compromise recognises that public and private schools of religious inspiration belong to the same public service of education and therefore have equal rights to public funding.
} 
schools have also been created following the prohibition of Muslim headscarves in public schools. $^{29}$

Catholic schools are run by OGEC (Organismes de Gestion de l'Enseignement Catholique, i.e. Catholic educational management organisations). OGEC associations are based on the $1901 \mathrm{Law}$, and are in charge of the legal, social, financial and real estate management of Catholic schools. They are federated at the departmental and national level and their voluntary boards must include a representative of the Catholic Church hierarchy.

In 2017, the percentages of students attending the three levels of private non-profit education, whether Catholic, of other religions or neutral was: ${ }^{30}$

- $13.5 \%$ in primary education

- $21.5 \%$ in secondary education

- $19 \%$ in tertiary education.

In the three educational levels, these percentages are growing slowly, more especially in tertiary education. Today, private education has better results ${ }^{31}$ than public education while the opposite was true 30 years ago and that is the main reason for most parents to choose private schools for their children, rather than out of religious considerations. Private schools are more middle-class oriented: they welcome $12 \%$ of pupils with scholarships, compared to $26 \%$ in public schools. As a result, private education is often seen as a source of inequality among the youth and France's Bishops' Conference and the federation of OGEC are currently examining ways of introducing more social diversity into the Catholic schools.

Even in its last refuge - education - the Church no longer has the power to decide. It can use the tools of soft power and influence students and teachers indirectly. However, the secularisation of this old, core area of the Church is today complete.

\section{Conclusion}

France has no doubt lost its specific relations between the Church and the State, as well as between civil society and the State. At the present stage in the country's welfare mix, it has been possible for two, opposing politicians to declare: "the State cannot do everything," Lionel Jospin when he was Socialist Prime Minister in 2002 (L'Etat ne peut pas tout); and the "State has no monopoly of the public good", declared by Jacques Chirac when he too was Prime Minister of a right-wing government in 1985 (L'Etat n'a pas le monopole du bien public).

In the country which is often seen as the archetype of State centralism, the mentalities are actually evolving. The vitality of civil society and the continuous growth of voluntary commitment explain a part of this change towards less State and more proximity and selforganisation. This is bringing France closer to its European neighbours. ${ }^{32}$ The sharing of educational, health and social services between the central and local government as well as civil society organisations obviously depends on the functions that have been devolved to

\footnotetext{
${ }^{29}$ Catholic schools welcome girls wearing the Muslim scarf as well.

${ }^{30}$ Ministère de l'Education et de la recherche (2018), Repères et références statistiques2018, http://www.education.gouv.fr/cid57096/reperes-et-references-statistiques.html

${ }^{31}$ The Ministry of Education publishes results corrected for the bias of parents' social origin.

${ }^{32}$ Archambault E.(2017): "Associations et pouvoirs publics: vers une convergence des modèles en Europe", Revue Française d'Administration Publique, n’163.
} 
local government, along with the level of externalisation or subcontracting which public authorities consider to be relevant. Recourse to civil society makes it possible to stabilise or reduce public employment, which is very high in France, and increases the quality of the services thanks to volunteers' value-added. Moreover, civil society also adapts itself more easily than the public sector to diversity across France's regions and populations. For its part, the public sector guarantees universal access to services provided and the equal treatment of all users. Various types of partnership contracting between the public and non-profit sectors make it possible to combine the advantages of both, while imposing regulation on the access to services and their permanence, in exchange for partial or almost total public financing of non-profit organisations.

France is no longer "the eldest daughter of the Church" as it was for the largest part of its history. Since the Revolution in 1789 - France's first huge step towards emancipation - the secularisation of the society has proceeded. Even in education, the most conflictual part of civil society, the Catholic Church has now accepted to pass from direct management to moral inspiration. Religious communities today influence some civil society charitable organisations directly such as the Secours Catholique, CIMADE (Protestant), Secours Islamique, OSE (Jewish), but most of them are secular. However many leaders and staff of health, welfare and education organisations are inspired by social Catholicism or Protestantism. In addition, surveys show that the most important variable correlated with giving and volunteering behaviour is the intensity of religious feeling and practice, in France as in many European and American countries. Representatives of religious communities are also members of ethical committees or are consulted on bioethical issues and major changes in society. However, it is not the sign of a "deprivatisation" of religion in France, ${ }^{33}$ but of the desire of the State to reinforce social links.

\footnotetext{
${ }^{33}$ Habermmas J. and Ratzinger J. (2007) The dialectics of secularisation. On reason and religion, San Francisco, Ignatius Press.
} 